Zoologica Poloniae (2009-2010) 54-55/1-4: 33-42

DOI: $10.2478 / \mathrm{v} 10049-010-0004-0$

\title{
METAMERIC MALFORMATIONS OF OPISTHOSOMA IN TEGENARIA ATRICA (ARANEAE, AGELENIDAE)
}

\author{
Julita Templin, Lech JACUŃSki and Teresa NAPIÓRKOWSKA
}

Department of Invertebrate Zoology, Institute of General and Molecular Biology, Nicolaus Copernicus University, Gagarina 9, 87-100 Toruń, Poland e-mail: templin@biol.uni.torun.pl

\begin{abstract}
The opisthosoma of Tegenaria atrica is characterized by a high morphological stability, as it is exceptionally resistant to the teratogenic effect of most abiotic factors except temperature. The least frequent opisthosomal anomalies found in our experimental material were disturbances in the colouring of opisthosoma. Another rare anomaly was the elongation of the postspinneret zone of the opisthosoma, resembling the postabdomen of other arachnids. The occurrence of a much narrower elongation, sometimes with traces of segmentation, resembling the postabdomen the advanced spider, can be interpreted as a specific atavism. An equally rare anomaly was the presence of two independent anal orifices in the postspinneret zone. All the abovedescribed anomalies appear extremely rarely, and some of them are related to the atavistic characteristics observed in the spiders' ontogeny.
\end{abstract}

\section{INTRODUCTION}

The opisthosoma of Tegenaria atrica C.L.Koch 1843, like that of other representatives of Araneae, is a body tagma clearly separated from the prosoma, whose full segmentation gets obliterated in the final phase of embryogeny. Morphogenetically it is characterized by a high morphological stability, as it is exceptionally resistant to the teratogenic effect of most abiotic factors. This stability can be disturbed by exposing the embryos to constant, supraoptimal temperature, and particularly to alternating temperatures (JACUŃSKI, 1984, 2002 a, b). It has been observed that particular parts of opisthosoma differ in their sensitivity to temperature (JACUŃSKI 1984, 2002 a, b). It is possible to distinguish sections that are more or less likely to be subject to developmental anomalies. 
The areas of the opisthosoma with no primordia of opisthosomal appendages or their derivatives are thought to be highly resistant to thermal shock. The first metamere and the postspinneret zone of the opisthosoma are among such areas. The most frequent anomalies of opisthosoma are minor changes in its shape, much less common are disturbances in its colouring and in the structure of its external spinning apparatus. The spinnerets, being transformed primordia of appendages, are subject to the same changes as the spiders' walking legs. Those anomalies consist in the lack of one or more spinnerets (oligomely), development of accessory spinnerets (polymely), coadunation of spinnerets of the same pair (symely) or of different pairs (heterosymely). There also occurs bifurcation of spinnerets (schistomely). An extremely rare anomaly is the appearance of elongation of the opisthosoma, which is considered to be an atavistic feature, related to the spiders' development from Haplogynae (JACUŃSKI, 1984, 2002b).

Further studies on the opisthosomal anomalies in T. atrica are aimed at compiling and describing more anomalies. They may elucidate the phylogeny of that part of the spiders' body. The paper presents selected cases of opisthosomal anomalies.

\section{MATERIAL AND METHODS}

The material for the study included embryos of $T$. atrica (family Agelenidae). The spider's eggs were exposed alternately to temperatures of $14^{\circ} \mathrm{C}$ and $32^{\circ} \mathrm{C}$ (6 and 18 hours in the first series, 18 and 6 hours in the second series respectively) at ca $70 \%$ relative humidity. When the first metameres appeared on the germ band, the primordia were exposed to the temperature that is optimal for their further development, i.e. $23^{\circ} \mathrm{C}$. After hatching, individuals with structural anomalies of the opisthosoma were selected for further study. In our experimental material (8371 embryos) 12 individuals showed anomalies of the external spinning apparatus. Moreover, 8 individuals showed changes in the colouring of opisthosoma. In two spiders we observed an elongation in the postspinneret zone, resembling the postabdomen, and two spiders had two independent anal orifices situated in the postspinneret zone.

\section{RESULTS}

Changes in colouring are among the least frequent opisthosomal anomalies. On the brown-grey background of Tegenarias' opisthosoma there are lighter yellow-grey spots forming a characteristic pattern. They are arranged symmetrically along the body long axis. The anterior most pair of spots, has the form of small transverse bands, the spots of the following pair are oval, the following four pairs are interconnected and arranged in the form of the upturned letter V, the next four are arranged archwise. The pattern on of the ventral side is formed by three longitudinal light, fairly wide bands running along the body, on a dark 
background. Disturbances of this characteristic pattern appeared in cases of anomalies in the external spinning apparatus. Changes in colouring affected mainly the pattern on the dorsal side of the opisthosoma and usually occurred in the section between the 4th and 6th pairs of spots. Disturbances in colouring of the dorsal side of the body were manifest mainly as an asymmetrical arrangement of the components of the pattern. The asymmetry was due to the fact that the spots concerned were larger or smaller than normal. Moreover, spots arranged in a line were often fused. Also fragments of the pattern were sometimes shifted or missing. It seems particularly noteworthy that the changes in the pattern appeared always on the same side of the body as the anomaly in the structure of the external spinning apparatus. However, no disturbances in the pattern were observed in the case of lack of the central spinneret. It also follows from our observations that anomalies in the external spinning apparatus do not usually induce significant changes in the design on the ventral side of the body (Fig. 1a,b).

Anomalies in the external spinning apparatus in most cases were already described by JACUŃSKI (1984), but new, very rare anomalies appeared. One of the abnormal individuals showed polymely, i.e. the presence of accessory (four) spinnerets. Those were a pair of central spinnerets and a pair of posterior ones coadunate at the base (heterosymely) which resulted in the formation of a complex of spinnerets situated atypically on the left side of the body. The spider in question had also a complete functioning set of spinnerets in its typical position (Fig. 2). Other rare anomalies in the external spinning apparatus were changes in the shape and arrangement of the spinnerets. Some of the spinnerets were strongly elongated, unnaturally thin, similar in shape to walking appendages, situated wide apart along the sides of the opisthosoma (Fig. 3). All the individuals affected with the above-described anomalies were in very good biological condition and usually reached the nymph VII stage, which is uncommon in individuals with developmental anomalies. They weaved very efficiently but in their nets there were no funnels characteristic of Agelenidae.

An extremely rare anomaly was found in two spiders: an elongation in the postspinneret zone resembling the postabdomen in other arachnids. In one of the individuals the opisthosoma was deformed, asymmetrical, with ring-like callosities in its posterior part, possibly traces of segmentation (Fig. 4). The length of the posterior part of the postabdomen - like structure constituted 1/ 6 of the length of a normal opisthosoma. In the other individual the opisthosoma was symmetrical, its posterior part resembling a postabdomen was uniform in structure, with no traces of metamerism and constituted 1/10 of the length of the whole opisthosoma (Fig. 5). In either case no anal orifice was found in the accessory part of the opisthosoma. The external spinning apparatus, however, was in its normal position. Individuals with that anomaly did not reach the nymph II ecdysis.

Another anomaly found in the opisthosoma of T. atrica was the presence of two independent anal orifices situated in the postspinneret zone. One of them was in its natural position, while the accessory one was shifted to the right side 

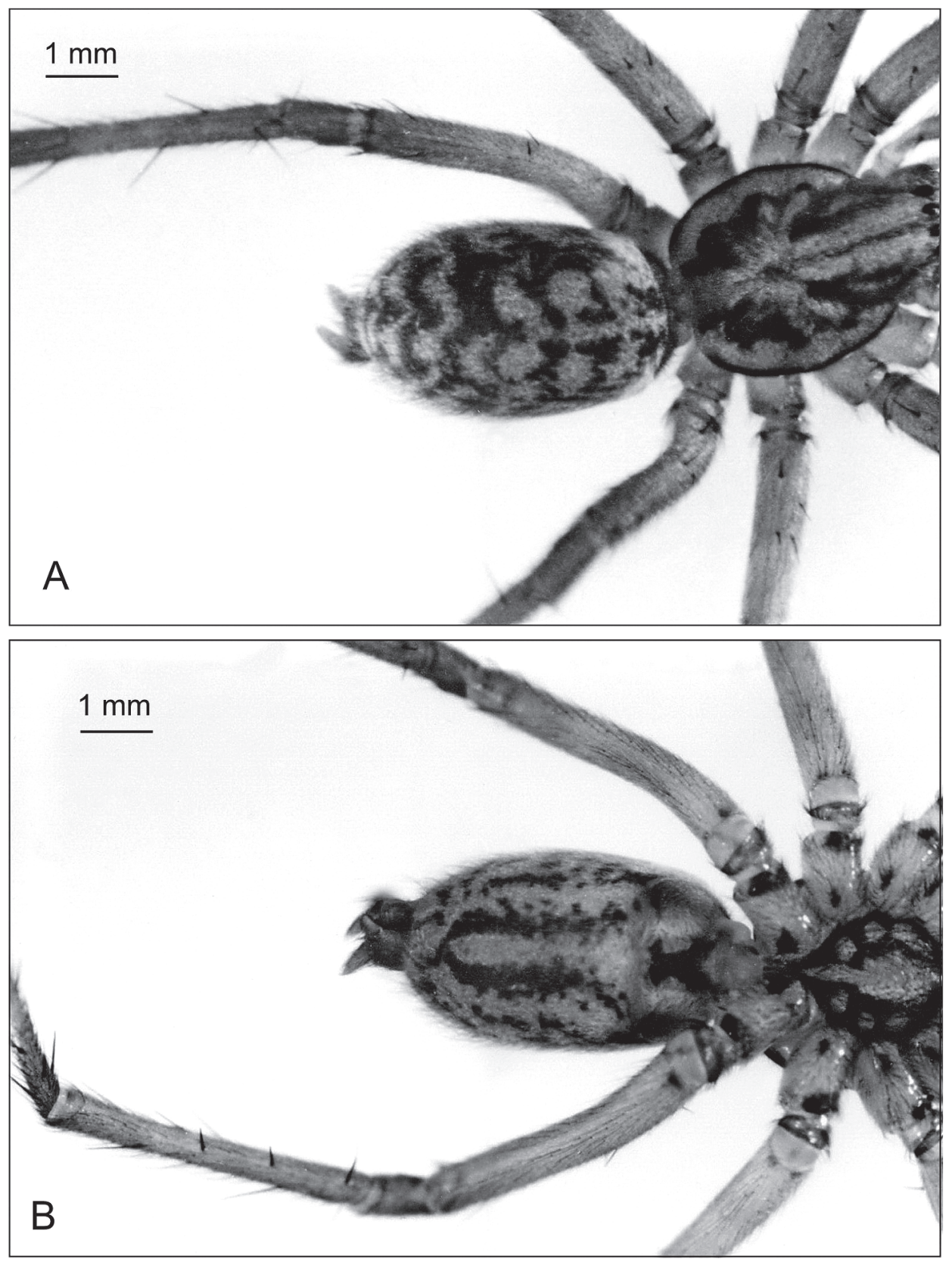

Fig. 1. Abnormal opisthosoma pattern in Tegenaria atrica: A - dorsal side, B - ventral side. 


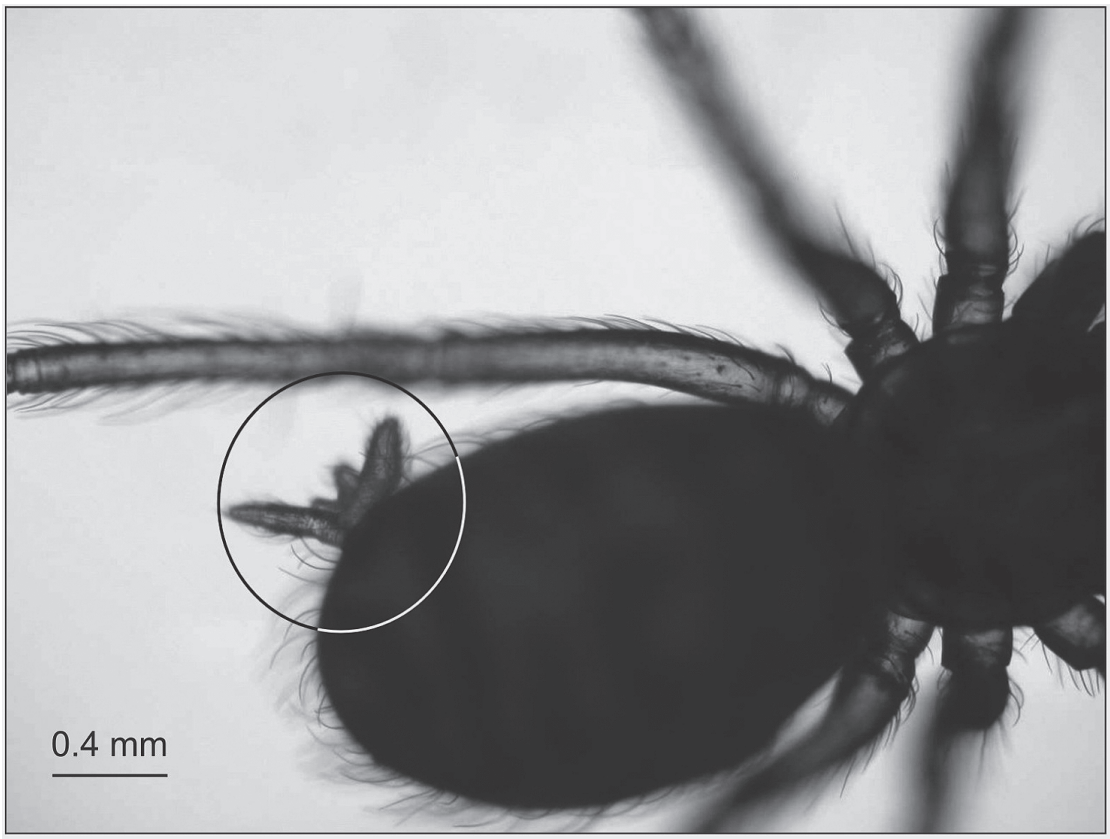

Fig. 2. Tegenaria atrica with an accessory complex of spinnerets situated on the lateral surface of opisthosoma.

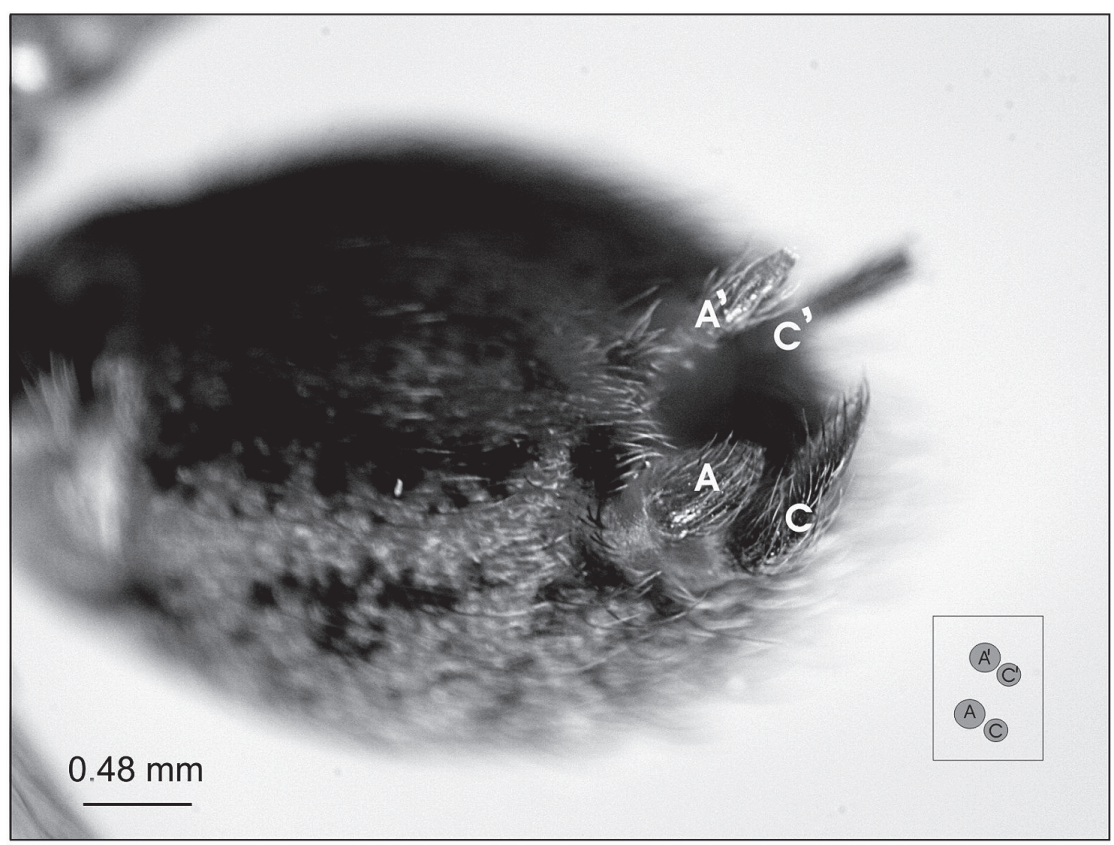

Fig. 3. Tegenaria atrica with strongly elongated spinnerets resembling walking appendages. 


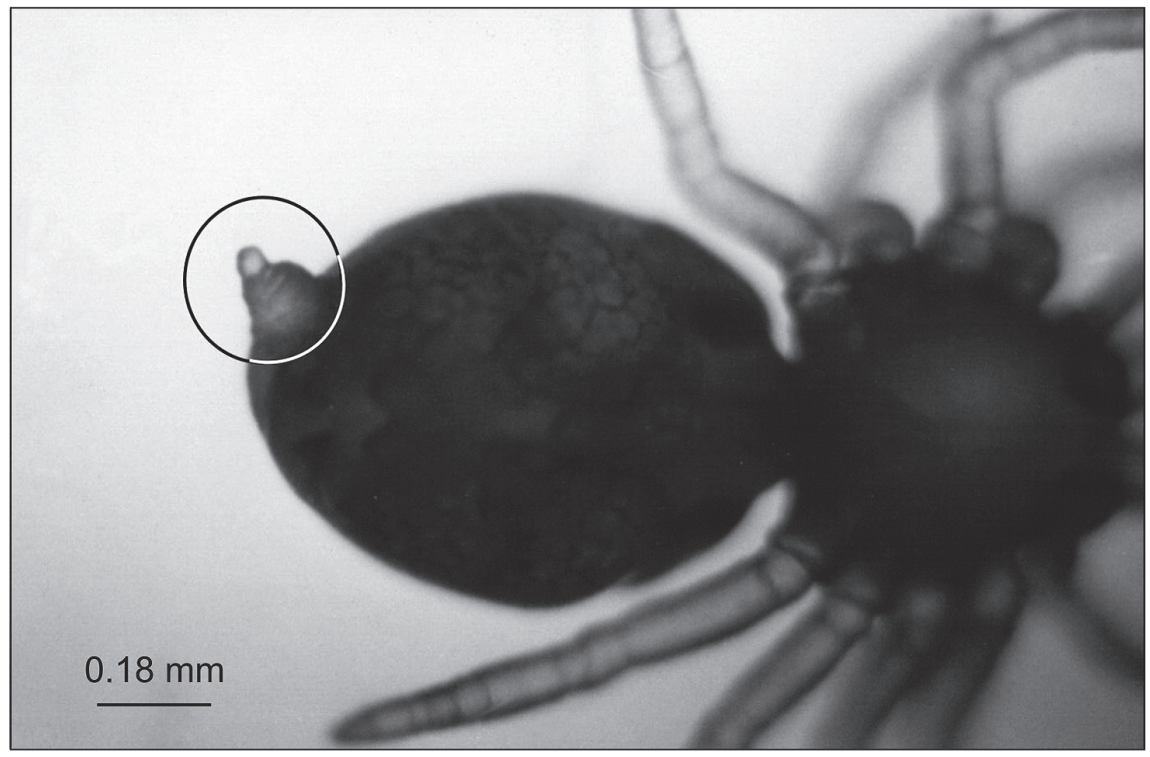

Fig. 4. Larva of Tegenaria atrica with postabdomen - like elongation of opisthosoma.

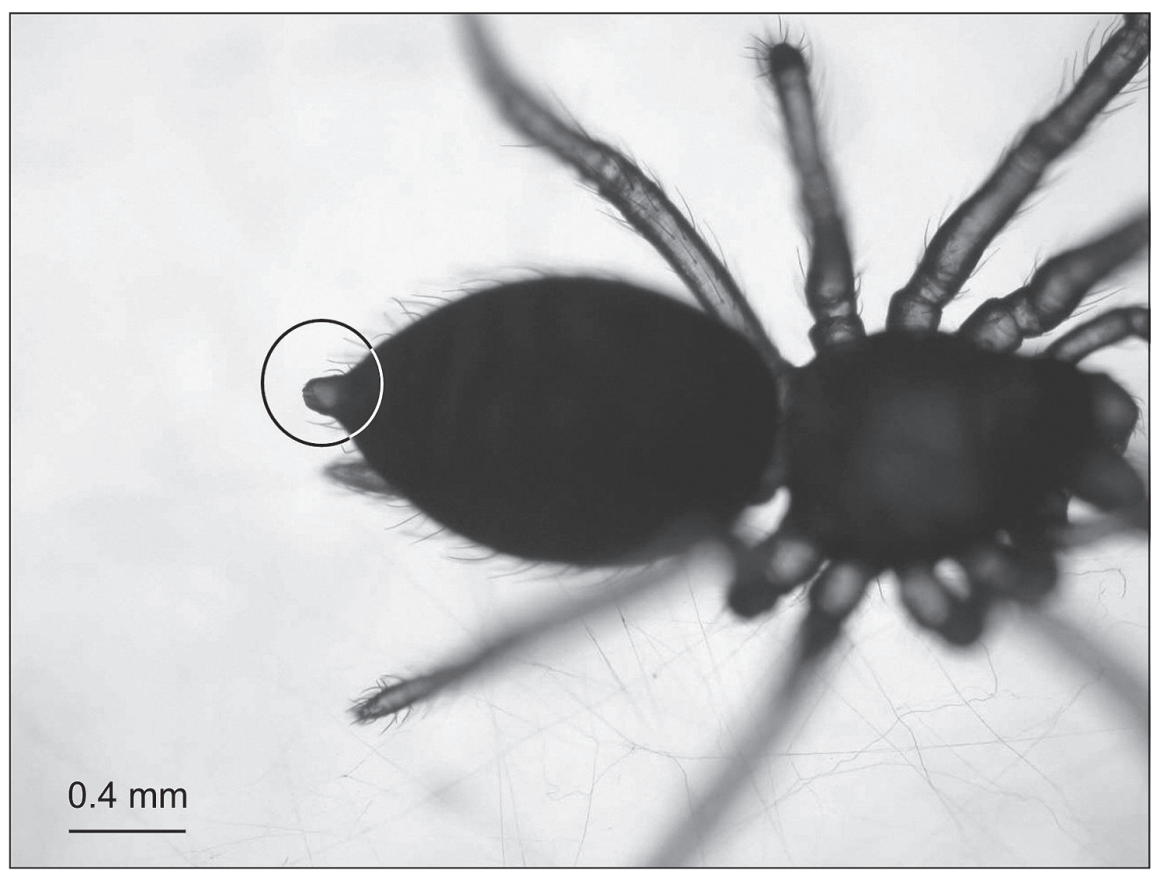

Fig. 5. Tegenaria atrica with postabdomen - like elongation of opisthosoma. 

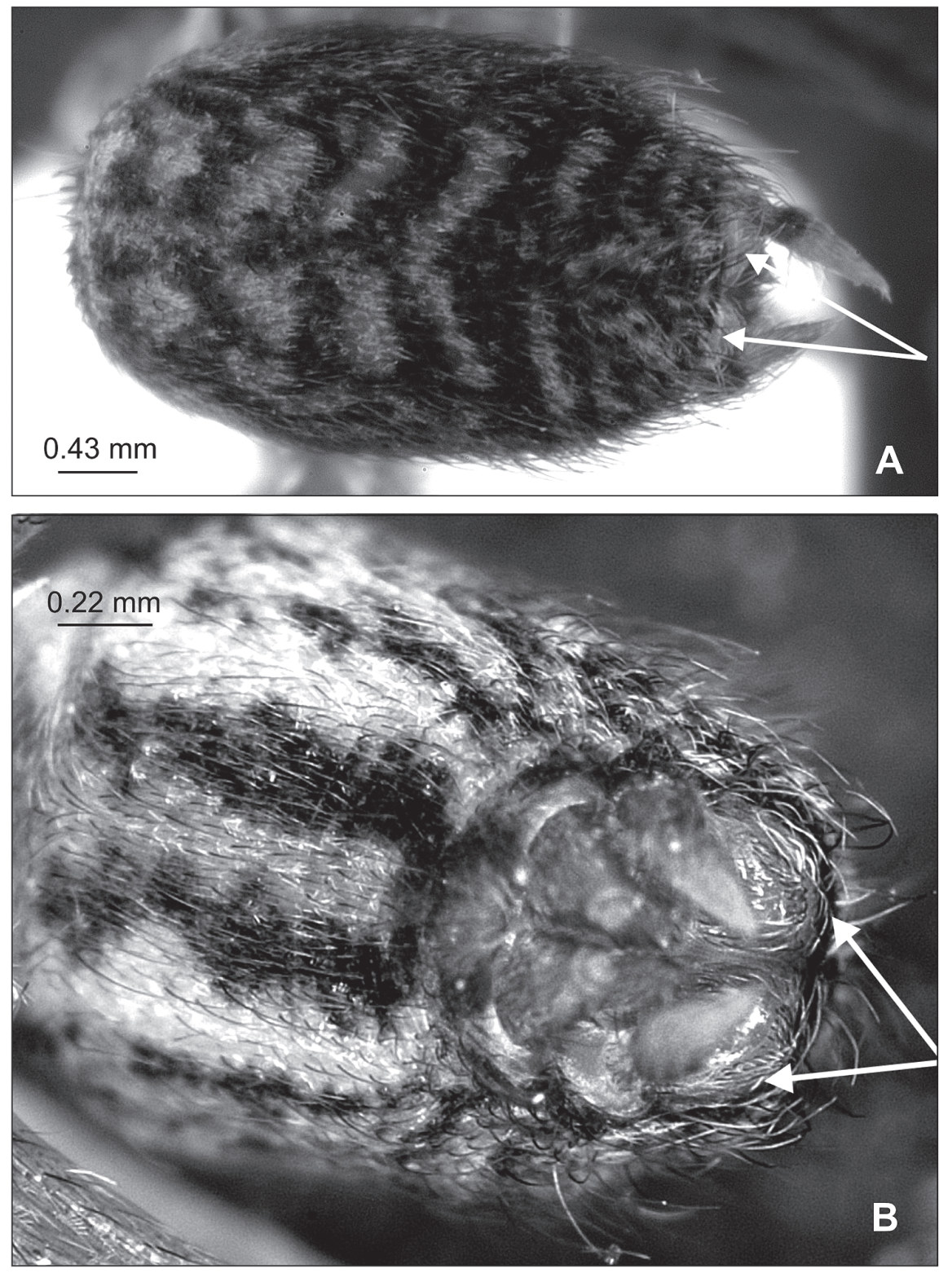

Fig. 6. Tegenaria atrica with bifurcate postspinneret zone of opisthosoma: A - dorsal side, B - ventral side.

of the body, facing the ventral side. In that individual there were also changes in the design on the dorsal side of the opisthosoma consisting in a slight bifurcation of the colour pattern at the end of the opisthosoma (Fig. 6 a,b). 


\section{DISCUSSION}

The arachnid opisthosomal tagma can be subject to developmental anomalies developing spontaneously in natural environment as well as under experimental conditions. The literature contains descriptions of spontaneous opisthosomal anomalies in Pseudoscorpionidea (ĆuRČIĆ, 1989 a, b; ĆURČIĆ and Dimitrijević, 1990; ĆurČić and DimitriJević, 1991; ĆurČić et al., 1991). Juberthie (1968), on the other hand, described anomalies in a representative of Opilionidae - Odiellus gallicus, and JACUŃSKI (1984, $2002 \mathrm{a}, \mathrm{b}$ ) - in T. atrica (Araneae); these anomalies were induced experimentally by using temperature as the teratogenic factor.

Anomalies found in our experimental material were disturbances in the colouring of the dorsal side of the opisthosoma. The diversity in the arrangement of the pattern characteristic of T. atrica was related to the changes in the metameric structure of that part of the body, since it was accompanied by disturbances in the architectonics of the external spinning apparatus, which is known to develop consistently with the metamerism of the opisthosoma. The spinnerets in individuals with modified opisthosoma colouring were subject to the same developmental anomalies as the prosomal appendages. Their common disturbances were oligomely, heterosymely, symely and polymely. Disturbances in the arrangement of particular pattern components and in the structure of the external spinning apparatus were associated with modifications in the arrangement of sternites. These cuticular structures, also forming metamerically, changed their size, joined together and changed places. Sometimes certain parts were missing or multiplied. Similar disturbances in the arrangement of sternites were described by JACUŃSKI (1984). The present observations confirm earlier theses on the close relationship between colouring, particularly that of the dorsal side of the opisthosoma of $T$. atrica, and the metameric structure of that tagma (Crome, 1955; Jacuński, 1984).

Colour anomalies in spiders were described already by Mikulska and Martinek (1964) and by Yaginuma (1971). In both cases colour changes were found in wild - living spiders. In the former case the changes affected only the opisthosoma, in the latter the whole body. The authors did not indicate any relationship between the colouring of the body and the changed metamerism of the opisthosoma.

An unusual anomaly was the elongation of the end part of the opisthosoma resembling the postabdomen in other arachnids but atypical in T. atrica. A similar case was described earlier in the same species (JACUŃSKI, 1984). The occurrence of a much narrower elongation, sometimes with traces of segmentation, resembling a postabdomen in the advanced spider Tegnaria, can be interpreted as a specific atavism. The postabdomen is known to have occurred in the extinct group Chelicerata-Gigantostraca. It also occurs in extant arachnids, such as scorpions, and spiders of the Haplogynae group (Holm, 1940; Ivanov, 1965; Yoshikura, 1975). The elongation of the end part of the body found in two of the spiders studied here resembled the postabdomen of Uropygi and Schizomida. 
Their postabdomen is short, much narrower than the remaining part of the opisthosoma, with no primordia of appendages.

Another anomaly was the appearance in the end part of the opisthosoma of two independent anal orifices. The deformity is probably due to a longitudinal duplication of the posterior section of the germ band of the "duplicitas posterior" type (SEKIGUCHI, 1957) in the part corresponding to the postspinnerets zone of the opisthosoma. In advanced spiders, such as T. atrica, that duplication is hardly visible due to the considerable condensation of the postspinneret zone of the opisthosoma in the final phase of embryogeny.

\section{METAMERYCZNE ZNIEKSZTAŁCENIA ODWŁOKA TEGENARIA ATRICA (ARANEAE, AGELENIDAE)}

\section{STRESZCZENIE}

Odwłok pająka Tegenaria atrica charakteryzuje się dużą stabilnością morfologiczną, ponieważ jest wyjątkowo odporny na działanie teratogenne większości czynników abiotycznych, za wyjątkiem temperatury. Do niezwykle rzadkich anomalii odwłokowych stwierdzonych w naszym materiale badawczym należą zmiany w ubarwieniu odwłoka. Inną rzadką anomalią było pojawienie się u badanego gatunku pająka w strefie zakądziołkowej wydłużenia, przypominającego zaodwłok występujący u innych pajęczaków. Pojawienie się znacznie węższego, czasem ze śladami segmentacji, wydłużenia podobnego do zaodwłoka u Tegenaria, który należy do pająków progresywnych, można zinterpretować jako swoisty atawizm. Kolejną wyjątkową anomalią stwierdzoną w odwłoku pająka Tegenaria atrica była obecność dwóch niezależnych otworów odbytowych położonych w strefie zakądziołkowej.

Wszystkie opisane anomalie pojawiają się w materiale teratologicznym niezwykle rzadko, część z nich nawiązuje do cech atawistycznych obserwowanych w ontogenezie pająków.

\section{REFERENCES}

Crome, W.,1955: Die Beziehungen zwischen dem dorsalen Zeichnungsmuster und der Metamerie des Spinnenabdomens. II Die Bedeutnug des Zieichnungsmusters und der dorsalen Längsmuskulatur für die Abdomen-Segmentierung der Mesothelae, Orthognatha und Labidiognatha; zugleich ein Beitrag zur Stammesgeschichte der Araeen-Unterordnungen. Zool. Jb., 83: 541-638.

ĆURČIĆ, B.P.M., 1989a: Segmental anomalies in some European Neobisiidae (Pseudoscorpiones, Arachnida). Part I Acta Arachn., 37: 77-87.

ĆURČIĆ, B.P.M., 1989b: Segmental anomalies in some European Neobisiidae (Pseudoscorpiones, Arachnida). Part II Acta Arachn., 38: 1-10.

ĆurČić, B.P.M., \& Dimitrijević, R.N., 1990: An example of partial duplication of the abdomen in Neobisium simoni (Pseudoscorpiones, Neobisiidae). J. Arachnol., 18: $113-115$. 
ĆurČić, B.P.M., \& DimitriJević, R.N., 1991: An example of abnormal carapace-abdominal fusion in Neobisium Aff. fuscimanum (Arachnida, Pseudoscorpiones, Neobisiidae). J. Arachnol., 19: 225-226.

Ćurčić, B.P.M., Dimitrijević, R.N., Kamarata, O.S. \& Lučić, L.R., 1991: Segmental anomalies in Roncus Aff. lubricus (Neobisidae, Pseudoscorpiones) from Yugoslavia. J. Arachnol., 19: 215-224.

Holm, Å., 1940: Studien über die Entwicklungsbiologie der Spinnen. Zool. Bidr. Upps., 19: 1-214.

Ivanov, A.V., 1965: Spiders, their morphology, biology and economic importance. Univ. Leningrad [In Russian.], 304pp.

JACUŃSKI, L., 1984: Studia nad teratogenezą eksperymentalną u pająka Tegenaria atrica C.L. Косн. UMK, Toruń, 72 pp.

JACUŃSKI, L., 2002a: Structural anomalies thermally induced in Tegenaria atrica C.L. Koch embryos. Bull. Pol. Acad. Sci. Biol., 50: 153-157.

JACUŃSKI, L., 2002b: Anomalies of the abdomen in Tegenaria atrica C.L. Koch (Araneae Agelenidae). Bull. Pol. Acad. Sci. Biol., 50: 183-188.

Juberthie, C., 1968: Tératologie expérimentale chez un Opilion (Arachnide). J. Embryo. exp. Morph. 19: 49-82.

Mikulska, I. \& Martinek, B., 1964: Anomaly in colouring in the spider Tegenaria atrica C.L. Кoch, 1843 [= Larva Simon, 1875]. Zool. Polon., 14: 3-8.

Sekiguchi, K., 1957: Reduplication in spider eggs produced by centrifugation. Sci. Rep. Tokyo Kyoiku Daig., (Section B) 8, 130: 187-240.

Yaginuma, T., 1971: A colour anomaly in the spider Heteropoda venatoria (LinNÉ) from Japan. Acta Arachn., 23: 21-23.

Yoshikura, M., 1975: Comparative embryology and phylogeny of Arachnida. Kumamoto J. Sci. Biol., 12, 2: 71-142.

Received 2010-09-01 